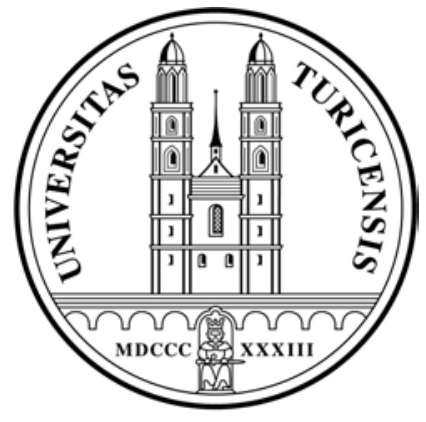

Institute for Empirical Research in Economics

University of Zurich

Working Paper Series

ISSN 1424-0459

Working Paper No. 256

\title{
The Relevance of Procedural Utility
}

for Economics

Matthias Benz

October 2005 


\title{
The Relevance of Procedural Utility for Economics
}

\author{
MATthias BENZ*
}

October 21, 2005

\begin{abstract}
This paper aims at showing the relevance of procedural utility for economics: people do not only care about outcomes, as usually assumed in economics, they also value the processes and conditions leading to outcomes. The psychological foundations of procedural utility are outlined and it is discussed how the concept differs from other related approaches in economics, like outcome utility, outcome fairness or intentions. Institutions at the level of society and fair procedures are shown to be sources of procedural utility, and novel empirical evidence on the role of procedural utility in important areas of the economy, polity and society is presented.
\end{abstract}

Keywords: procedural utility, outcome utility, institutions, procedural fairness, outcome fairness, intentions

JEL-Codes: A00, A12, D60, D70

\footnotetext{
* Institute for Empirical Research in Economics, University of Zurich, Bluemlisalpstrasse 10, 8006 Zurich, Switzerland. Phone: +41-1-634 37 31; Fax: +41-1-634 49 07; E-mail: matbenz@iew.unizh.ch; and CREMA - Center for Research in Economics, Management and the Arts. Much of the material contained in this article is based on ideas that were developed together with Bruno S. Frey and Alois Stutzer. I am grateful to them and to the participants of the CESifo Workshop on Economics and Psychology in Venice, 18.-19. July 2005, for helpful remarks and discussions, and I have received valuable suggestions from two anonymous referees on how to improve the paper.
} 


\section{Introduction}

Economic science is based on the view that people care about outcomes. Consider, for example, a situation where individuals are involved as litigants in an arbitration process. At the end of the arbitration procedure, people have to choose whether to accept a court-ordered, but non-binding award, or rather to go on to have a formal trial. From an economic perspective, there is a clear-cut prediction how people will behave in such a situation. They will compare the two alternatives at hand and choose the one that offers the higher expected monetary payoff (e.g. Cooter and Ulen 2000, 377-381). Yet in reality, people seem to behave quite differently. In a seminal study on real-life arbitration procedures, Lind et al. (1993) showed that outcome considerations were only modestly important for individuals' decisions to accept a court-ordered award. Rather, what litigants seemed to judge as crucial was the fairness of the arbitration procedure applied. When individuals felt they were treated in a respectful, impartial and trustworthy way by the court authorities and they were given due voice in the arbitration process, they were much more likely to accept a court-ordered award, irrespective of monetary outcomes that involved sums of up to US\$ 800'000.

In this article, it is argued that procedural utility similar to the one involved in the arbitration example emerges in many areas of economic and social life, and as a consequence, it should be incorporated more widely into economic theory and empirical research. The general concept of procedural utility means that people do not only care about outcomes, but also value the

processes and conditions leading to outcomes. People often do not only care about the 'what', but also about the 'how', or yet in other words, they value the 'means' beyond the 'ends'. Procedural utility represents a quite different approach to human well-being and behavior than the standard approach applied in economics. But there is a considerable body of empirical evidence indicating that individuals care about processes in their own right. I discuss eight areas relevant for economics: consumption, work and employment, political participation, public good provision, taxes, inequality and redistribution, organizations and the law. In each area, individuals have been found to derive direct utility from the institutions and procedures applied beyond considerations for material outcomes.

The present paper extends and complements an earlier survey article by Frey, Benz and Stutzer (2004) that set out to introduce the concept of procedural utility into economics. In comparison to 
the earlier work, this paper more thoroughly details the concept of procedural utility and discusses how the concept differs from other related approaches in economics, like outcome utility, inequality aversion (outcome fairness) or intentions. Moreover, the paper presents novel and additional evidence on the role of procedural utility in several areas of the economy, polity and society. Section II begins by outlining the psychological foundations of the concept of procedural utility and shows the differences to other approaches in economics. Moreover, the main sources of procedural utility are presented, namely institutions at the level of society (the decision-making mechanisms of the market, hierarchy and democracy), and on a smaller scale, fair procedures applied in social relationships. In section III, the concept is applied to eight areas relevant for economics and novel empirical evidence is presented on the existence of procedural utility in these areas. Section IV concludes the paper by discussing how the concept of procedural utility can fruitfully be integrated into the traditional economic approach.

\section{The Concept of Procedural Utility}

\section{Beyond Outcomes}

When economists apply economic theory to concrete problems and questions, they typically assume that human utility consists of outcomes only, as showcased by the arbitration example described in the introduction. Three additional examples shall illustrate the outcome-orientation of the economic approach, two relating to the field of institutional economics and one relating to organizational economics.

Consider, first, a situation where a group of people, e.g. a minority group, is granted the democratic right to vote. In economics, it is typically assumed that people value this voting right because it allows them to change the outcomes of the political process in their favor. The minority group, for example, can alter the scope or composition of public goods provided or it can vote for redistributive measures benefiting the group (e.g. Mueller 2003: 79-84). While such outcome aspects are without doubt important, a procedural view focuses more on the direct utility that people may get from the voting right. Individuals might attach a high value to democratic rights simply because they give them a sense of inclusion, identity and self-determination. This procedural utility can persist even if the voting right does not substantially affect political outcomes. 
Imagine, as a second example, people subject to hierarchical decision-making. Individuals working within a hierarchy often have different degrees of autonomy over their work content and how to do their work. Economists typically assume that employees value such decision-making authority if it leads to better outcomes, e.g. in the form of a higher income (e.g. Williamson 1975: 39, Aghion and Tirole 1997, Baker, Gibbons and Murphy 1999). The concept of procedural utility, conversely, suggests that people may have a preference for autonomy in itself. Increased autonomy may be seen as a good decision-making procedure, because it provides individuals with a direct utility from having control over their work.

Third, envisage firms planning to undertake nominal wage cuts in times of recession. Economic models predict that workers often resist such wage cuts, either because they individually constitute a bad outcome or because workers see them as unacceptable in terms of outcome fairness vis-à-vis the firm (e.g. Bewley 1999, Fehr and Götte 2005). A procedural perspective, in contrast, emphasizes the processes by which pay cuts are announced and undertaken. Employees' reactions to pay cuts may be less averse if they happen through fair processes, e.g. when management thoroughly and sensitively explains the basis for the pay cuts (Greenberg 1990a). As a result, procedural aspects can have real consequences, as they may help to avoid unnecessary layoffs and lower the rate of unemployment at the level of the economy.

The three examples illustrate the outcome-orientation of the economic approach. When economic theory is applied to concrete problems and questions, human utility is often reduced to outcome considerations. This may in part reflect that important theoretical cornerstones of economics, like expected utility theory or game theory, generally define preferences over monetary payoffs (Harsanyi 1993). But in many respects, this restraint is odd. Economics, in principle, is a science that is deliberately vague about what human preferences are defined over. During the positivistic movement of the 1930's, economists just gave up the idea that utility could be observed directly and adopted the view that the only way to infer utility was from revealed behavior. But in principle, what individuals value could be anything. Economics is thus potentially open to the integration of many forms of human needs and desires. Some non-material human motives that have received attention recently in economics include, for example, identity (e.g. Akerlof and Kranton 2000, 2004), status (e.g. Frank 1985) or respect, self-esteem and pride (e.g. Khalil 1996, Köszegi 2002a,b). In principle, economics is also open to the notion that individuals enjoy 
procedural utility. So far, only a few economists have argued against the economic tendency to see outcomes as the only source of utility and the only driving force behind behavior. Most prominently, Sen $(1995,1997)$ has repeatedly stressed that economic choice models should combine preferences for outcome with those for processes (but see also Anand 2001, Le Menestrel 2001 and Sandbu 2004).

\section{Psychological Foundations}

The general concept of procedural utility means that individuals do not only care about outcomes, but also value the processes and conditions leading to outcomes. People do not only care about the 'what', but also about the 'how', or they value the 'means' beyond the 'ends'. In order to reintegrate procedural utility into economics, the psychological foundations of the concept have to be outlined. Procedural utility rests on three building blocks that deviate in important respects from standard economics, but that are well grounded in research in other social science disciplines.

(i) Procedural utility emphasizes utility as well-being. Utility is understood in a broad sense as pleasure and pain, positive and negative affect or life satisfaction. ${ }^{1}$ This reinstates the original economic idea that utility consists of everything that individuals value. Economists have recently rediscovered well-being as a direct measure of human utility, based on a substantial amount of research on reported subjective well-being or happiness strongly influenced by social psychology (see Frey and Stutzer 2002a,b, Diener et al. 1999 and Oswald 1997 for surveys).

(ii) Closely connected with this first point, procedural utility takes a broad view on the determinants of human utility. It posits that processes and institutions under which people live and act are independent sources of utility, apart from the outcomes that they also produce. People may judge an unfavorable outcome as acceptable if the procedure applied was 'good', and a favorable outcome might provide them with little overall satisfaction if the procedure that brought it about was 'bad'. In this sense, procedures and decision-making mechanisms cannot only be judged in terms of outcomes, as it is traditionally done in economics.

\footnotetext{
${ }^{1}$ Daniel Kahneman has coined the term 'experienced utility' for this notion of utility, in contrast to traditional 'decision utility' (e.g. Kahneman et al. 1997).
} 
(iii) Procedural utility emerges because people have a sense of self. The way by which things are done provides individuals with important feedback information about how they have to perceive themselves and how they are perceived by others. Different procedures and decision-making mechanisms in addition allow people to live and act according to their own self-image to a different extent. By focusing on people's sense of self, the concept of procedural utility reincorporates a central tenet of social psychology into economics (see e.g. Baumeister 1998 for a survey). In recent decades, psychologists have developed a detailed understanding of the basic psychological needs of the human self, which is most stringently summarized in "selfdetermination theory" by Ryan and Deci (2000). ${ }^{2}$ Three innate needs have been found to be essential: autonomy, competence and relatedness. The desire for autonomy encompasses the experience to self-organize one's own actions or to be causal. The need for competence refers to the propensity to control the environment and experience oneself as capable and effective. And the need for relatedness refers to the desire to feel connected to others in love and care, and to be treated as a respected group member within social groups. Different procedures can be expected to provide different procedural goods serving these innate needs. Importantly, procedures that address innate psychological needs contribute to individual well-being beyond outcomes traditionally studied by economists. For example, self-determination theory stresses that procedures providing individuals with autonomy are not valued so much because they lead to better outcomes, but because having control over one's actions satisfies a basic psychological need of human beings.

Taken together, the three building blocks form a concept of procedural utility that can in general be applied to all situations where human action is shaped and constrained by procedures and institutions. The psychological foundations of the concept permit the derivation of theoretical hypotheses on when procedural utility is expected to be more pronounced and when it is expected

\footnotetext{
${ }^{2}$ Self-determination theory by Deci and Ryan (2000) can be seen as a summary of manifold underlying theories that stress similar motives of the self. Related theories comprise, for instance, people's urge to master their environment for its own sake (White 1959) and of being an origin (DeCharms 1968), people's resistance to loss of control (Brehm 1966) and the reflection of perceived control in more effective behavior and higher positive affects (Bandura 1977, Peterson 1999 and Seligman 1992). Based on similar reasoning on human functioning several categorizations of the dimensions of well-being have been proposed, for instance, self-acceptance, positive relations with others, autonomy, environmental mastery, purpose in life and personal growth (Ryff and Keyes 1995). In the literature on procedural justice, several psychological models have linked procedural justice to the human self, e.g. Tyler and Blader (2003).
} 
to be less important. This makes the concept falsifiable. In sum, procedural utility can be defined as the well-being people gain from living and acting under institutionalized processes as they contribute to a positive sense of self, addressing innate needs of autonomy, competence and relatedness.

\section{Sources of Procedural Utility}

Procedural utility can emerge from different sources. These sources can be classified into two broad categories:

First, there is the procedural utility people get from institutions. At the level of society, the most important formal systems for reaching decisions are the price system (market), democracy, hierarchy, and bargaining (Dahl and Lindblom 1953). People may gain procedural utility from these institutions because they differently address innate needs of autonomy, competence and relatedness, beyond shaping outcomes. The direct effects that institutions can have on individuals' well-being make procedural utility a particularly relevant concept for institutionally oriented social sciences, like institutional economics.

Second, procedural utility emerges in interactions between people. People evaluate actions towards them not only by their consequences, but also by how they feel treated by other persons. This form of procedural utility has extensively been researched in the large literature on procedural fairness or procedural justice (see e.g. Lind and Tyler 1988), which can be considered the best investigated aspect of procedural utility. People have been repeatedly found to care about procedural fairness beyond outcomes, in particular when they deal with authorities in the public as well as private sphere.

Of course, there is often a smooth transition between the two categories. Institutions on the one hand select and motivate people how to treat their fellow workers, citizens and consumers. In a democracy, for example, politicians and public bureaucrats can be expected to treat citizens differently than in an autocracy. On the other hand, people who evaluate institutions, processes or authorities usually base their judgment on the treatment experienced by the specific people involved. In this respect, the procedural utility effects of institutions will always be mediated to 
some extent by social interactions occurring within these institutions (see e.g. Blader and Tyler 2003 on related evidence).

While the sources of procedural utility may sometimes be hard to distinguish, this does not mean that the concept could be applied arbitrarily. Whether procedural utility emerges from institutions like the market mechanism, democratic decision making, or hierarchy as such, or whether it stems from procedural differences on a smaller scale, e.g. from procedural differences within an organization, a political system or a legal framework, there is a common ground to all these channels of impact: individuals judge processes positively to the extent that they address innate needs of self-determination. Theoretical hypotheses are therefore possible. With respect to procedural differences on a smaller scale, there is a clear understanding from the literature on 'procedural fairness' about what constitutes a good procedure. As procedures on this level often involve how authority is exercised in organizations, public administrations or legal contexts, innate needs are mainly affected by relational information that procedures convey, such as assessments of impartiality, trustworthiness of superiors and authorities, the extent to which individuals feel they are treated with dignity, and the extent to which individuals are given voice (see e.g. Tyler et al. 1997). When institutions at a larger scale are considered, like democracy or hierarchy, one can derive similar hypotheses. This can be illustrated by the examples given at the outset of this section. For instance, democratic rights are expected to have positive procedural utility effects because they enhance individuals' perception of self-determination. Hierarchical decision-making, in contrast, is likely to produce procedural disutility because it interferes with individuals' self-determination. Empirical results along these lines will be presented in section III.

\section{Differences to other approaches in economics}

While procedural utility has not been seriously integrated into economics so far, a few related approaches exist that have received some attention in the economics profession. In this subsection, it is discussed how the procedural utility view distinguishes itself from these approaches. Apart from the distinction to traditional outcome utility already discussed, three seem most important: preferences for gambling, inequality aversion (outcomes fairness) and intentions. 
First, the term "process utility" is sometimes used in the economic literature on preferences for gambling. Already Pascal (1670) considered the utility gained from gambling as an interesting phenomenon, and later Marschak (1950) and von Neumann and Morgenstern (1953) showed that it is incompatible with expected utility maximization. Recently, Le Menestrel (2001) established axioms for a model of rational decisions under risk and uncertainty combining processes and consequences, explicitly using the term ,process utility“ to describe the utility that people derive from acts like gambling. While gambling indeed may involve process aspects, there are important differences to the concept of procedural utility as proposed here. Gambling (in a non-pathological form) may also qualify as non-tangible consumption, which is readily accessible with the standard approach in economics. The important difference to the procedural utility concept proposed here is that gambling, like other forms of non-tangible consumption, does typically not involve a "procedurally intense" environment. The concept of procedural utility stresses that a comparative view of different procedures and institutions should be undertaken with regard to how they address innate needs of self-determination. To the extent that procedures and institutions fulfill this role, they create procedural utility and affect human well-being beyond outcomes.

Second, economists have paid considerable attention recently to integrating outcome fairness into individual utility functions (e.g. Bolton and Ockenfels 2000, Fehr and Schmidt 1999, Konow 2003). These theories have in common with the concept of procedural utility that detailed considerations are made about what human utility consists of. However, there are also important differences. On the one hand, models of "inequality aversion" remain grounded in an outcomeoriented view traditional in economics, while procedural utility stresses that processes and institutions affect human utility beyond outcomes and also outcome fairness. In the literature on procedural justice, this difference has been researched in detail and it has been repeatedly shown that people care about fair processes beyond aspects of individual outcomes as well as of distributional fairness (e.g. Lind and Tyler 1988, Tyler and Blader 2000). On the other hand, the procedural utility concept employs a comparative institutional view that is typically absent from the literature on inequality aversion. For example, from the point of view of outcome fairness, it should make no difference to people's well-being in a country whether a given income distribution was brought about by a democratic or dictatorial regime. The procedural utility perspective suggests that people might well judge the two situations differently, because they 
attach a value to institutions in their own right (see also Sen 1995 on this point, and the evidence discussed in section III.6).

Third, the approach most closely related to procedural utility in economics is the notion that intentions matter for human well-being and behavior. Theories of intentions assume that people care about how they are treated by others in social interactions, irrespective of monetary payoffs or distributional aspects. Several aspects broadly related to intentions have been identified and experimentally tested in the economic literature, like "reciprocity" (e.g. Falk, Fehr and Fischbacher 2003, Falk and Fischbacher 2000, Rabin 1993), "betrayal aversion" (Bohnet and Zeckhauser 2004), "process-dependent preferences" (Sandbu 2004), or "procedural fairness" as opposed to "allocation fairness" (Bolton, Brandts and Ockenfels 2005). Despite of similarities, there remain substantial differences to the concept of procedural utility. On the one hand, intentions are most closely related to the large literature on procedural fairness, but the latter research has developed a quite more detailed understanding in terms of psychological content of what intentions actually consist of real-life relationships (see e.g. Lind and Tyler 1988 for a survey). Economic experiments so far have employed a rather narrow view of intentions, typically showing that people judge a bad outcome distribution as more acceptable if it was produced by a random mechanism than when it was deliberately chosen by another person. On the other hand, the concept of procedural utility goes far beyond procedural fairness aspects alone. Importantly, it stresses that institutions at the level of society, like the market, democracy or hierarchy, can have effects on human well-being beyond outcomes. Thus, the concept of procedural utility employs a comparative institutional approach, encompassing also the fundamental decision-making mechanisms that shape the organization of societies.

In sum, procedural utility is a concept that is distinct from outcome utility as traditionally studied in economics; it is based on foundations well researched in the psychological literature; it emerges from sources of great relevance for economic analysis, like institutions at the level of society and on a smaller scale fair processes employed in social relationships; and it is distinct from related approaches that have received some attention in the economic literature, like preferences for gambling, outcome fairness and intentions. 


\section{The Relevance of Procedural Utility: Empirical Evidence}

Whether procedural utility is a fruitful category ultimately rests on its empirical relevance. In this section, empirical evidence from a broad range of areas is discussed where procedural utility has been shown to matter. Eight areas seem particularly relevant for economics: consumption, work and employment, political participation, public good provision, taxes, inequality and redistribution, organizations and the law.

\section{Consumption}

Consumption is probably an area where procedural utility would not be expected: it generally takes place on well functioning markets where transactions are focused on material outcomes. Nevertheless, procedural utility has been found to play a role in consumer decisions. Frey and Pommerehne (1993), in a study extending a famous investigation by Kahneman, Knetsch and Thaler (1986), analyze consumers' reactions to different allocation mechanisms in an excess demand situation. In particular, it is investigated how consumers rate different institutional mechanisms to allocate a limited number of water bottles to hikers at a hilltop on a hot day. $73 \%$ of the respondents surveyed consider a price increase for the water bottles to be an unfair means to overcome the shortage, and thus rate a normal functioning of the market mechanism as unacceptable. In contrast, other decision-making mechanisms fare better. An allocation by "tradition" (first come, first served) is considered by far less people to be unfair (24\%), and similarly an allocation by administrative procedures (by the local authorities) is reckoned unfair by $57 \%$. Only a random allocation fares worse than the price system; only to $14 \%$ of the respondents it appears to be acceptable. The study thus suggests that consumers' overall evaluations of allocations are not just dependent on outcomes. In particular, the market mechanism is opposed as a rationing mechanism despite of the fundamental economic insight that it leads to the most efficient results. Procedures seem to play an independent role for consumers' utility, although it is not yet well understood why alternative allocation mechanisms may serve innate psychological needs of consumers better than the price system.

On a less institutional level, people have been found to care about their perceived treatment as customers beyond outcome considerations. In an experimental study on consumer boycotts, for example, Tyran and Engelmann (2005) show that boycotts in reaction to price increases are often 
undertaken although they fail to hold down prices and are not profitable for consumers. They are also undertaken irrespective of whether collective action problems prevail (successful boycotts are a public good). Rather, the experimental findings suggest that consumers undertake boycotts in order to punish sellers for apparently 'unfair' price increases. People seem to be emotionally negatively affected when they perceive behavior towards them as exploitation, most likely because it undermines their status as consumers who are presumed to be on an equal standing with producers. If consumers have such procedural concerns, this can impose a constraint on profit maximization by suppliers, affecting market equilibrium and even macroeconomic variables (see e.g. Rotemberg 2005).

Consumers, in addition, may also care about more than just price and quality when buying a good. Kysar (2004) argues that consumers often have preferences for how a good is produced, in particular for whether the production process conforms to basic environmental standards or labor regulations. For example, people may prefer to buy an otherwise identical shoe when the production process respects certain worker rights. If consumers satisfy not only material needs by buying a good, but also the self-image of a conscious consumer, there is a case for the mandatory provision of the relevant process information to consumers. Reliable knowledge about the characteristics of a good's production process helps consumers to purchase according to their procedural preferences; the resulting 'political' consumption choice can even substitute for uniform regulations enacted in the political process.

Overall, the probably most interesting question related to consumption choices is whether the market mechanism as the fundamental institution of capitalist economies is a source of procedural utility. The evidence presented in Frey and Pommerehne (1993) suggests that in situations of excess demand, the use of market prices is often vigorously opposed by the individuals involved. But this does not mean that in more general situations, the market could not be valued by individuals as an attractive institution in procedural terms. Interestingly, related arguments have been rather made in the psychological literature than by economists who typically defend the market on efficiency grounds. A long tradition in social psychology has argued that freedom of choice, which is the defining characteristic of decision-making on markets, satisfies an important basic psychological need of human beings (e.g. Brehm 1966, deCharms 1968, Heider 1958, White 1959). Empirical studies have repeatedly shown that individuals enjoy higher well-being if they can choose among alternatives, compared to a 
situation where an alternative is imposed from outside (irrespective of objective outcomes, see e.g. Brehm 1966, Botti 2002, Cordova and Lepper 1996, Langer and Rodin 1976, Schulz and Hanusa 1978, Zuckerman et al. 1978). As a consequence, the psychological literature has largely reached a consensus that people value freedom of choice because it allows them to satisfy innate psychological needs of autonomy, control and self-determination (but for contrasting views, see e.g. Loewenstein 2000, Iyengar and Lepper 2000, Schwartz 2000). Thus, the market mechanism cannot only be defended as an institution promoting outcome efficiency, as typically in economics. The market can also be seen as a source of procedural utility, because it provides individuals with possibilities of self-determination. ${ }^{3}$

\section{Work and employment}

When individuals act as income earners, they are often confronted with the institution of hierarchy. Hierarchy means that production and employment are integrated into an organization, and decisions are characterized by some degree of authority. Hierarchy can be considered to be the most fundamental institution by which decisions are taken in society with respect to work organization and production, and is thus an essential and widespread feature of the economy.

Does hierarchy involve procedural utility aspects? The theoretical arguments discussed in section II lead to a clear proposition: Individuals prefer independence to being subject to hierarchical decision making. Hierarchy constitutes a procedural disutility because it interferes with innate needs of self-determination: autonomy and the experience of competence are generally restricted under hierarchy, and strongly related to independence.

Frey and Benz (2003) present an empirical test of whether individuals enjoy procedural utility from independence vs. hierarchy. They exploit the idea that earnings can in principle be generated in two ways: in a hierarchy (as an employee) or independently (as a self-employed person). Using individual panel data from the United Kingdom, Germany and Switzerland, they find that self-employed people indeed enjoy higher utility from their work (measured via job satisfaction) than employees, even if important outcomes like pay level, working hours, and

\footnotetext{
${ }^{3}$ In fact, this view is only defensively articulated in economics, if at all. A rare example for a procedural support of the market system by a liberal economist is by James Buchanan (1986, p. 22): „To the extent that voluntary exchange among persons is valued positively while coercion is valued negatively, there emerges the implication that substitution of the former for the latter is desired, on the presumption, of course, that such substitution is technologically feasible and is not prohibitively costly in resources".
} 
many others are controlled for. ${ }^{4}$ Benz and Frey (2003) moreover show for a sample of 23 countries from different world regions that the higher job satisfaction of the self-employed can directly and fully be explained by their higher autonomy, and not by other, outcome-related factors. Self-employed people seem to enjoy their position as independent actors on the market, and of not being subject to a hierarchy, for purely procedural reasons, because autonomy and independence are seen as characteristics of a good decision-making procedure.

There is also evidence for the related hypothesis that satisfaction is (ceteris paribus) the lower the larger the hierarchy an employee is subject to. Frey and Benz (2003) show that in the United Kingdom, Germany and Switzerland, people working in large firms are considerably less satisfied with their jobs than people working in small organizations. Idson (1990) finds a similar result for the United States and shows that the lower job satisfaction of workers in larger firms can mainly be explained by procedural factors: “ $[\ldots]$ workers in larger establishments have a significantly lower level of freedom on their jobs concerning what type of work they do and how they do it, and face significantly greater rigidity with regards to hours and days of work" (p. 1013). Procedural utility thus seems to be of great relevance also for people working in dependent employment.

The notion that autonomy and job control are sources of procedural utility at work finds further support in the Whitehall studies undertaken by Michael Marmot and co-authors (e.g. Marmot et al. 1997, Marmot 2004). The Whitehall studies show that individuals working at lower levels of the British civil service have a considerably higher likelihood of developing coronary heart diseases than individuals working at the highest levels of the organizational hierarchy. Marmot et al. (1997) document that this "social gradient" in health can to a large extent be explained by procedural work aspects. While standard coronary risk factors, such as smoking, and factors acting early in life, as represented by physical height, account for a part of the social health gradient, the largest factor contributing to the higher frequency of coronary heart diseases among people in lower employment grades is their low job control. This finding suggests that a lack of

\footnotetext{
${ }^{4}$ Similar results on job satisfaction of self-employed people have been found by Blanchflower and Oswald (1998), Blanchflower (2000), Blanchflower, Oswald and Stutzer (2001), Hundley (2001) and Kawaguchi (2002). Frey and Benz (2003), Kawaguchi (2002) and Hundley (2001) moreover use an individual-fixed-effects methodology in panel data to show that the higher job satisfaction of self-employed people is not due to different time-invariant personality characteristics. Non-monetary benefits of self-employment and entrepreneurship are also documented in Hamilton (2000) and Moskowitz and Vissing-Jorgensen (2002). For a general overview arguing that entrepreneurship should be seen as a non-profit-seeking activity, see Benz (2005a).
} 
autonomy at work does not only to affects individuals' well-being in the form of low procedural utility, but that it also translates into substantially worse health.

Procedural aspects within hierarchies have also been studied in other contexts that are more related to the role of procedural fairness in work relationships. It is, for example, a well-known fact that workers often resist nominal pay cuts. The resulting downward wage rigidity has macroeconomic consequences because it can cause excess unemployment in recessions (e.g. Bewley 1999, Fehr and Götte 2005). For workers' resistance to pay cuts, not only issues of outcome or distributional fairness seem to be crucial, but also process considerations. It has been shown, for example, that employees' reactions to pay cuts are less averse if this happens through fair processes, e.g. when management thoroughly and sensitively explains the basis for the pay cuts (Greenberg 1990a). This finding has quite profound implications. It means that by applying fair procedures, firms could more easily implement necessary wage cuts in times of recession, which would reduce the rate of unemployment in the economy.

In sum, procedural utility seems to be an important factor of what individuals value in their work lives. On the one hand, procedural utility is the result of autonomy and control at work, or the absence of hierarchical decision-making, which is valued by individuals beyond standard outcome considerations. On the other hand, procedural utility emerges if fair procedures are applied in work relationships (see also section III.7). While labor economists and organizational economists usually do not deny that 'bad working conditions' may cause disutility, the nonpecuniary aspects of autonomy, job control, and procedural fairness are typically not taken into account in formal models (see e.g. Aghion and Tirole 1997, Baker, Gibbons and Murphy 1999). Taking procedural utility seriously, however, may also enrich economic analyses of work and organizations.

\section{Democratic participation}

In the realm of politics, the institution of democracy represents the fundamental mechanism by which decisions are taken in society. Irrespective of the precise form of a democracy, citizens' rights to participate in political decisions are a crucial characteristic of any democratic constitution. Participation rights may be completely absent in an autocracy or dictatorship. In representative democracies, they typically comprise the right to vote in elections and to run for a 
seat in parliament, and in direct democracies, they additionally entail possibilities of launching and voting on referenda and initiatives. Citizens may gain procedural utility from such participation rights over and above the outcome generated in the political process, because they provide a feeling of being involved and having political influence, as well as a notion of inclusion, identity and self-determination. By being able to participate, citizens may feel that the political sphere takes their wishes seriously into account in a fair political process; if participation is restricted, they may feel alienation and apathy towards the political institutions installed. Indeed, a large literature in the social sciences, especially in psychology, political science and sociology, attributes a positive value to participation, as it enhances individuals' perception of self-determination (for an extensive survey see Lane 2000, chapter 13).

Can it be empirically shown that citizens derive procedural utility from political participation rights? A study by Frey and Stutzer (2005) employs an empirical identification strategy based on the idea that the status of being a national fundamentally differs from that of being a foreigner. Nationals have the right to vote and to participate in political decision-making, while foreigners do not have these rights. Nationals should thus derive more utility from political participation rights than foreigners if they enjoy procedural utility. This hypothesis is tested econometrically using a survey based on more than 6'000 interviews with residents of Switzerland, where there is a unique variation in the political participation rights among citizens. In addition to elections, citizens have access to direct democratic instruments (initiatives, referenda) which differ substantially from canton to canton. As a proxy measure for utility, an index of reported subjective well-being is used as the dependent variable. The estimated overall utility effect from more extended political participation rights, as reflected in reported life satisfaction, is in itself sizeable. Citizens, as well as foreigners, living in jurisdictions with more developed political participation rights enjoy higher levels of subjective well-being. The positive effect on reported satisfaction with life is, however, smaller for foreigners, reflecting their exclusion from procedural utility. The positive effect of participation rights is about three times larger for the citizens than it is for the foreigners, i.e. a major part of the welfare gain from favorable political procedures seems to be due to procedural utility. The results hold ceteris paribus, i.e. when a large number of determinants or correlates of subjective well-being (in particular sociodemographic characteristics, employment status, household income and proxies for political outcomes) are controlled for. 
The procedural utility of political participation rights may also be reflected in revealed behavior. In an experimental study before the elections to the German parliament in 1994, Güth and WeckHannemann (1997) investigated what amount of money would have to be paid to individuals in order to make them destroy their personal voting card, thereby giving up their right to vote in this particular election. Despite of the fact that a single vote almost never changes the outcome of an election, most individuals are not willing to sell their voting right even for high amounts of money. $63 \%$ of voters refuse to destroy their voting card even for the highest sum offered (DM 200, approx. US\$ 100 at the time), and only 5\% agree to give up their voting right for less than DM 10 (approx. US\$ 5). These findings show that individuals place a high value on their voting right that goes beyond any outcome utility they may get from altering the election result. Rather, political participation rights seem to be a source of procedural utility, because they enhance individuals' possibilities of self- and co-determination.

\section{Public good allocation}

Governments often face resistance to public projects generally considered important and desirable, such as finding suitable locations for hospitals for the mentally deranged or handicapped, for airports or for nuclear waste. Such "NIMBY"-projects are often supported by the general population, but nobody wants to see them in their neighborhood (hence 'Not In My Back Yard'). The economic approach suggests that the most straightforward solution to this problem is to use a market mechanism: prospective gainers must be taxed and the revenue must be redistributed to the prospective losers hosting the public project (e.g. Kunreuther and Kleindorfer 1986, O'Sullivan 1993). But in reality, procedures based on the price system have been found to rarely, if ever, work (e.g. Frey and Oberholzer 1997). Individuals seem to consider monetary compensation as a bribe that disregards their sense of self as decent citizens and that seems to involve negative procedural utility. Other forms of compensation that do more justice to people's concerns have been found to work better. For example, if compensation is offered along a predetermined dimension (e.g. airport noise is compensated by helping people to insulate their homes), the chances of project acceptance increase, although this form of transfer is inefficient according to traditional welfare theory, because it's not fungible.

More generally, different allocation procedures have been found to greatly affect people's willingness to host a public project. A study by Frey and Oberholzer (1996) investigates the 
acceptability of various decision-making procedures for siting a noxious facility in Switzerland. The persons interviewed rank procedures in the following order: negotiations (bargaining) are seen by $72 \%$ as an acceptable procedure of siting, $32 \%$ find referenda (democracy) to be acceptable, $26 \%$ a decision by lottery, and only a few see the price system as an acceptable procedure (20\% in the form of willingness to accept, and $4 \%$ in the form of willingness to pay). Further analyses revealed that "acceptability" is seen by respondents as consisting of three components: "security", "local influence" and "fairness". It transpired that the ranking in terms of "fairness" exactly mirrors the above given ranking in terms of acceptability. Thus, the results can clearly be interpreted in procedural terms. It is not only the implication for the outcomes (like the extent of local influence) that causes people to find a siting procedure more or less acceptable. Rather, individuals seem to attach an independent, procedural value to the different allocation mechanisms. It is noteworthy that similar results have also been found for the allocation of publicly provided services to citizens and consumers, e.g. in the area of health care (Wailoo and Anand 2005, Tsuchiya et al. 2005).

\section{Taxes}

The payment of taxes to finance the provision of public goods and redistributive measures is an important element in the relationship between citizens and the state. In principle, procedural utility can play a twofold role in this relationship. First, the political institutions used to determine tax rates and tax spending may influence citizens' satisfaction with the state's functioning beyond outcomes. Second, on a lower level, taxpayers may respond in a systematic way to how the tax authority treats them, e.g. their willingness to pay taxes may be supported or even raised when the tax officials treat them in a procedurally fair way.

In recent years, empirical evidence for both channels of influence has been found, emphasizing the role of procedural aspects in taxation. With respect to institutional determinants, it has mainly been investigated how democratic participation rights affect of people's willingness to pay taxes. Several experimental studies have shown that individuals evade less taxes if they have the possibility to vote on tax measures (e.g. Alm, McClelland and Schulze 1999, Feld and Tyran 2002, Torgler, Schaltegger and Schaffner 2003). The impact of voting thereby holds over and above outcome aspects, i.e. factors like the probability of punishment for tax evasion, the size of the fine applied, the tax rate, individual incomes, and the 'efficiency' of the state are carefully 
held constant in the experiments. Related results have been found in econometric field studies. For example, Pommerehne and Weck-Hannemann (1996) show that tax evasion is lower in those Swiss cantons where citizens have more extended direct democratic participation rights, and Torgler (2005) documents a similar finding using survey data on tax morale.

Procedural aspects also have been found to play a role in the direct relationship between citizens and tax authorities. Evidence reported in Feld and Frey (2002) and Frey and Feld (2002), using a sample of Swiss cantons in the years 1970-1995, suggests that individuals care about how they are treated by tax authorities. When tax collectors deal with citizens in a respectful way, people seem to avoid less taxes. Moreover, the tax authorities on average behave as if they were aware of the reaction of taxpayers to being treated with respect or not. For example, deterrence is only one of the motivational forces used by the authorities; often, they rely on respectful procedures of tax collection.

While procedural utility aspects in taxation certainly have to be investigated in more detail to corroborate their importance, the evidence discussed shows that new insights on tax compliance and tax evasion may be gained by taking procedural utility into account. Without doubt, the procedural approach greatly extends the classical economic model of taxpayer behavior that is based on pure outcome considerations (Allingham and Sandmo 1972, Andreoni, Erard and Feinstein 1998: 824-835, Slemrod and Yitzhaki 2002) and that has not been very successful in explaining people's willingness to pay taxes empirically (e.g. Alm, McClelland and Schulze 1992: 22).

\section{Redistribution and inequality}

Social inequality is a pervasive phenomenon in many societies. Most governments aim at reducing social inequality at least to some extent by applying redistributive measures that tax the rich and benefit the poor. What explains citizens' support of such redistributive measures, or rather their opposition towards them?

In economics, the probably most dominant view is that individuals' support of redistribution is dependent on their own position in the income distribution (i.e., being rich or poor), or if they are forward looking, on their prospects of upward income mobility (for an early account, see Hirschman 1973). Bénabou and Ok (2001) have proposed an influential model based on this 
outcome-oriented view, arguing that individuals oppose redistribution more if social income mobility is high. However, objective measures of upward income mobility have been found to explain individuals' demand for redistribution only to a limited extent (e.g. Alesina and La Ferrara 2005, Fong 2005). The empirical evidence rather suggests that individuals' support of redistributive measures depends on how the primary distribution was brought about. If people believe that success mainly depends on individual effort, they consider redistribution to be less necessary than when they believe that success mainly depends on luck; conversely, if people think that poverty is predominantly caused by factors beyond individual control, they support redistribution (e.g. Fong 2001, Fong 2005).

This evidence on individuals' demand for redistribution sheds a distinctly procedural light on the question of social inequality. People seem to judge a given income distribution not only in terms of individual outcomes or outcome fairness, but also to a considerable extent based on the social processes that brought it about. If social processes provide everyone with a fair chance to "make it", inequality is considered less of a problem than when social processes are biased and unfair. This suggests that "equality of opportunities" can be seen as a source of procedural utility. The theoretical arguments made in section II indeed support such an interpretation. On the one hand, people may value equality of opportunities in procedural terms because it gives everyone the chance to lead a self-determined life and to be the master of one's own fate. On the other hand, equality of opportunities signals that everyone in principle is considered to be a respected member of society. Individuals may care about both aspects beyond outcomes, because they address the innate needs of self-determination that form the basis of procedural utility. Recently, Bénabou and Tirole (2005) have included an aspect similar to this kind of procedural utility into a formal model of redistribution (which they call the "need to believe in a just world").

\section{Organizations}

Organizations are the field where aspects of procedural utility have been most intensely studied. As in hierarchies, many decisions are taken in an "authoritarian" way, research has mainly focused on the effects of procedural fairness on well-being and behavior. The literature on procedural fairness or justice in organizations is so large that there already exist meta-analyses (e.g. Cohen-Charash and Spector 2001). The studies consistently find that concerns for procedural fairness are a highly relevant and widespread phenomenon in the employment 
relationship. It has been shown to matter for employees' behavior, satisfaction, and attitudes in areas like change (mergers and acquisitions, layoffs, restructuring, strategic planning) and human resources (personnel selection, performance evaluation, and compensation; see Konovsky 2000 and Colquitt et al. 2001 for overviews, and Lind et al. 2000 for an exemplary empirical study). Procedural aspects that researchers have identified as important include organizational policies and rules, like providing advance notice for decisions and opportunities for voice (see e.g. Greenberg 1990b and Lind and Tyler 1988), but they also encompass the interpersonal treatment of people (Bies and Moag 1986). Individuals have been found to generally value fair procedures over and above organizational outcomes. Procedural fairness effects prevail when individual outcomes as well as aspects of distributional fairness are controlled for in the analysis (e.g. Tyler and Blader 2000). Thus, procedural utility is without doubt a relevant part of what individuals value when working in organizations.

A study by Benz and Stutzer (2003) may serve as an empirical example for the relevance of fair procedures in work relationships. The authors study the satisfaction people derive from their pay, using a representative sample of over $22^{\prime} 000$ British workers. The results show that pay satisfaction is not only influenced by absolute outcomes (the compensation people get for a given input) or relative outcomes (people's pay in relation to comparable workers' pay), but most strongly by procedural factors. In particular, employees that are frequently consulted on pay issues by their superiors are ceteris paribus considerably more satisfied with their pay than workers that are never asked in matters of compensation. Thus, organizational procedures that support a fair pay determination process are found to affect employees' well-being beyond material outcomes.

\section{Law}

Similar to organizations, procedural aspects are likely to be important in law because people often are subjected to decisions by authorities. Law is thus an area where procedural utility in the form of procedural fairness has been thoroughly studied. Many studies find that people react adversely to unfair legal procedures, irrespective of the objective judgment made by a court. Unfair procedures lead individuals to rate the legitimacy of authorities and their satisfaction with a trial lower, and it also affects subsequent compliance behavior (see e.g. Tyler 1997, 2003 for overviews). 
One study has already been summarized as an example in the introduction, because it investigates real life behavior and thus will be of most interest to economists. Lind et al. (1993) studied the acceptance of awards from court-ordered arbitration by real life litigants, which included corporate and individual litigants in Federal Courts. The authors find that litigants who judge the arbitration process as fair are much more likely to accept the court-ordered award (irrespective of the objective outcome). The decision to go on to have a formal trial was most strongly influenced by procedural fairness considerations. This is remarkable, as the disputes considered involved amounts of money of up to US\$800'000. The objective size of the award and other outcome factors also predicted acceptance, although to a much lesser extent. Thus, the study shows that utility from procedures plays a role in lawsuits over and above outcome utility.

\section{Concluding Remarks}

People do not only care about outcomes, they also value the processes and conditions leading to outcomes. This "procedural utility" is a concept that is distinct from outcome utility as traditionally studied in economics; it is based on foundations that are well researched in the psychological literature; it emerges from sources of great relevance for economic analysis, like institutions at the level of society and on a smaller scale fair processes employed in social relationships; and it is distinct from related approaches that have received some attention in the economic literature, like outcome fairness and intentions. Procedural utility has been found to play an important role for individuals' well-being in many areas of the economy, polity and society. The empirical evidence discussed in this paper suggests that people care about processes in their own right in their role as consumers, employees, citizens, taxpayers, members of society and individuals subject to various public and private authorities. As a consequence, economic science can gain from incorporating the concept of procedural utility more widely into economic theory and empirical research.

How could such an integration of procedural utility into the traditional economic approach look like? It has to be stressed that the concept of procedural utility in principle does not contradict the theoretical economic understanding of utility, which is based on the view that utility consists of everything that individuals value. However, procedural utility stands in contrast to how utility is 
usually defined in applications of economic theory to concrete problems and questions, and to how utility is used in many formal economic models. Therefore, an integration of procedural utility into the economic approach mainly requires an extended view of human well-being. In empirical research, a broader view seems relatively straightforward to implement. For example, the relative importance of "good procedures" and "good outcomes" can often be studied within the same empirical framework by using data on life or job satisfaction as measures for individual well-being, as illustrated in the empirical section III. With respect to theoretical work, an integration of procedural utility into formal economic theory seems to be more of a challenge that remains to be addressed by future work. However, the development of formal models that take human concerns for processes and outcomes simultaneously into account may be guided by the theoretical considerations and psychological foundations outlined in section II (see also Frey, Benz and Stutzer 2004 for a broader discussion).

While evidence discussed in this paper inspires economic analysis and reasoning about economic policy in areas like consumption, work and employment, people's willingness to accept public undertakings or to pay taxes, and issues of social inequality, law or organizational policies, there surely is room for promising further research in several so far unexplored directions. For example, the concept of procedural utility may be applied to other political institutions not considered in this paper, like fiscal federalism or majoritarian vs. proportional electoral systems. Fiscal federalism may be a source of procedural utility because it allows for decentralized, autonomous political decisions, and proportional electoral systems may be valued in procedural terms because they allow for a broader, more inclusive political representation. In the realm of economic organization, the notion that hierarchy involves procedural disutility might add to our understanding of the boundaries of the firm, and it might provide new insights into the organization of work. For example, not-for-profit firms tend to apply systematically different organizational procedures than for-profit firms, probably because procedural utility is a precondition for the particular pro-social motivation that non-profit workers have to possess (see e.g. Benz 2005b). For issues of redistribution, not only the social procedure of "equality of opportunities" might matter, but also whether transfers are in cash or in kind, or whether they are publicly or privately funded. Fair procedures are likely to shape conflict resolution, e.g. in bargaining between unions and firms. Finally, procedural aspects may be crucial for how people perceive discrimination in the workplace and in public life. An examination of these and related 
questions promises to add to a deeper understanding of human well-being and behavior beyond standard economic outcome considerations. 


\section{References}

Aghion, Philippe and Jean Tirole (1997). Formal and Real Authority in Organizations. Journal of Political Economy 105(1): 1-29.

Akerlof, George A. and Rachel E. Kranton (2000). Economics and Identity. Quarterly Journal of Economics 115(3): 715-753.

Akerlof, George A. and Rachel E. Kranton (2004). Identity and the Economics of Organizations. Journal of Economic Perspectives 19(1): 9-32.

Alesina, Alberto and Eliana LaFerrara (2005). Preferences for Redistribution in the Land of Opportunities. Journal of Public Economics 89(5/6): 897-931.

Allingham, Michael G. and Agnar Sandmo (1972). Income Tax Evasion: A Theoretical Analysis. Journal of Public Economics 1 (3-4), 323-338.

Alm, James, Gary H. McClelland and William D. Schulze (1992). Why Do People Pay Taxes? Journal of Public Economics 48(1): 21-38.

Anand, Paul (2001), Procedural Fairness in Economic and Social Choice: Evidence from a Survey of Voters. Journal of Economic Psychology 22(2): 247-270.

Andreoni, James, Brian Erard and Jonathan Feinstein (1998). Tax Compliance. Journal of Economic Literature 36(2): 818-860.

Baker, George, Robert Gibbons and Kevin J. Murphy (1999). Informal Authority in Organizations. Journal of Law, Economics and Organization 15(1): 56-73.

Bandura, Albert (1977). Self-Efficacy: Toward a Unifying Theory of Behavior Change. Psychological Review 84: 191-215.

Baumeister, Roy F. (1998). The Self. In: Daniel T. Gilbert, Susan T. Fiske and Gardner Lindzey (eds). The Handbook of Social Psychology, vol. 1. New York and Oxford: Oxford University Press.

Bénabou, Roland and Efe Ok (2001). Social Mobility and the Demand for Redistribution: The POUM Hypothesis. Quarterly Journal of Economics 116(2): 447-87.

Bénabou, Roland and Jean Tirole (2005). Belief in a Just World and Redistributive Politics. NBER Working Paper No. 11208.

Benz, Matthias (2005a). Entrepreneurship as a Non-Profit-Seeking Activity. Institute for Empirical Research Working Paper No. 243, University of Zurich.

Benz, Matthias (2005b). Not for the Profit, but for the Satisfaction? - Evidence on Worker WellBeing in Non-Profit Firms. Kyklos 58(2): 155-176.

Benz, Matthias and Alois Stutzer (2003). Do Workers Enjoy Procedural Utility? Applied Economics Quarterly 49(2): 149-172.

Benz, Matthias and Bruno S. Frey (2003). The Value of Autonomy: Evidence from the SelfEmployed in 23 Countries. Institute for Empirical Research Working Paper No. 173, University of Zurich.

Bewley, Truman E. (1999). Why Wages Don't Fall During a Recession. Cambridge and London: Harvard University Press. 
Bies, R. J. and J.S. Moag (1986). Interactional Justice: Communication Criteria of Fairness. In: R. J. Lewicki, B. H. Sheppard and B. H. Bazerman (eds.). Research on Negotiation in Organizations, vol. 1. Greenwich: JAI Press: 43-55.

Blader, Steven L. and Tom R. Tyler (2003). A Four Component Model of Procedural Justice. Personality and Social Psychology Bulletin 29(6): 747-758.

Blanchflower, David G. (2000). Self-employment in OECD Coutries. Labour Economics 7(5): 471-505.

Blanchflower, David G. and Andrew Oswald (1998). What Makes an Entrepreneur? Journal of Labor Economics 16(1): 26-60.

Blanchflower, David G., Andrew J. Oswald and Alois Stutzer (2001). Latent Entrepreneurship Across Nations. European Economic Review 45(4-6): 680-691.

Bohnet, Iris and Richard Zeckhauser (2004). Trust, Risk and Betrayal. Journal of Economic Behavior \& Organization 55(4): 467-484.

Bolton, Gary E. and Axel Ockenfels (2000). ERC: A Theory of Equity, Reciprocity, and Competition. American Economic Review 90(1): 166-93.

Bolton, Gary E., Jordi Brandts and Axel Ockenfels (2005). Fair Procedures: Evidence from Games Involving Lotteries. Economic Journal, forthcoming.

Botti, Simona (2002). Preference for Control and its Effect on Evaluation of Consumption Experience. Working Paper, Graduate School of Business, University of Chicago.

Brehm, Jack W. (1966). A Theory of Psychological Reactance. New York: Academic Press.

Brockner, Joel and Batia M. Wiesenfeld (1996). An Integrative Framework for Explaining Reactions to Decisions: Interactive Effects of Outcomes and Procedures. Psychological Bulletin 120(2): 189-208.

Buchanan, James M. (1986). Liberty, Market and the State. Brighton: Wheatsheaf.

Cohen-Charash, Yochi and Paul E. Spector (2001). The Role of Justice in Organizations: A Meta-Analysis. Organizational Behavior and Human Decision Processes 86(2): 278-321.

Colquitt, Jason A., Donald E. Conlon, Michael J. Wesson, Christopher Porter and. K. Yee Ng (2001). Justice at the Millenium: A Meta-Analytic Review of 25 Years of Organizational Justice Research. Journal of Applied Psychology 86(3): 425-445.

Cooter, Robert and Thomas Ulen (2000). Law and Economics. $3^{\text {rd }}$ edition. Reading: AddisonWesley.

Cordova, Diana I. und Mark R. Lepper (1996). Intrinsic Motivation and the Process of Learning: Beneficial Effects of Contextualization, Personalization, and Choice. Journal of Educational Psychology 88(4): 715-730.

Dahl, Robert A. and Charles E. Lindblom (1953). Politics, Economics and Welfare: Planning and Politico-Economic Systems Resolved into Basic Social Processes. Harper: New York.

DeCharms, Richard (1968). Personal Causation. New York: Academic Press.

Deci, Edward L. and Richard M. Ryan (2000). The "What" and "Why" of Goal Pursuits: Human Needs and the Self-determination of Behavior. Psychological Inquiry 11(4): 227-268.

Diener, Ed, Eunkook M. Suh, Richard E. Lucas and Heidi L. Smith (1999). Subjective WellBeing: Three Decades of Progress. Psychological Bulletin 125(2): 276-303. 
Easterling, Douglas H. and Howard Kunreuther (1995). The Dilemma of Siting a High-Level Nuclear Waste Repository. Boston: Kluwer.

Falk, Armin, Ernst Fehr and Urs Fischbacher (2003). On the Nature of Fair Behavior. Economic Inquiry 41(1): 20-27.

Falk, Armin and Urs Fischbacher (2000). A Theory of Reciprocity. University of Zurich, Institute for Empirical Research in Economics Working Paper No. 6.

Fehr, Ernst and Klaus M. Schmidt (1999). A Theory of Fairness, Competition, and Cooperation. Quarterly Journal of Economics 114(3): 817-68.

Fehr, Ernst and Lorenz Götte (2005). Robustness and Real Consequences of Nominal Wage Rigidity. Journal of Monetary Economics 52(4): 779-804.

Feld, Lars P. and Bruno S. Frey (2002). Trust Breeds Trust: How Taxpayers Are Treated. Economics of Governance 3: 87-99.

Feld, Lars P. und Jean-Robert Tyran (2002). Tax Evasion and Voting: An Experimental Analysis. Kyklos 55(2): 197-222.

Fong, Christina (2001). Social Preferences, Self-Interest, and the Demand for Redistribution. Journal of Public Economics 82: 225-46.

Fong, Christina (2005). Prospective Mobility, Fairness, and the Demand for Redistribution. Working Paper, Carnegie Mellon University.

Frank, Robert H. (1985). Choosing the Right Pond. New York: Oxford University Press.

Frey, Bruno S. and Matthias Benz (2003). Being Independent is a Great Thing. Subjective Evaluations of Self-Employment and Hierarchy. Institute for Empirical Research in Economics Working Paper No. 135, University of Zurich.

Frey, Bruno S., Matthias Benz and Alois Stutzer (2004). Introducing Procedural Utility: Not Only What, But Also How Matters. Journal of Institutional and Theoretical Economics 160(3): 377-401.

Frey, Bruno S. and Lars P. Feld (2002). Deterrence and Morale in Taxation: An Empirical Analysis. Mimeo. Institute for Empirical Research in Economics, University of Zurich.

Frey, Bruno S. and Felix Oberholzer-Gee (1996). Fair Siting Procedures: An Empirical Analysis of Their Importance and Characteristics. Journal of Policy Analysis and Management 15(3): 353-376.

Frey, Bruno S. and Felix Oberholzer-Gee (1997). The Cost of Price Incentives: An Empirical Analysis of Motivation Crowding-Out. American Economic Review 87(4): 746-755.

Frey, Bruno S. and Werner W. Pommerehne (1993). On the Fairness of Pricing - An Empirical Survey among the General Population. Journal of Economic Behavior and Organization 20(3): 295-307.

Frey, Bruno S. and Alois Stutzer (2002a). Happiness and Economics: How the Economy and Institutions Affect Human Well-Being. Princeton: Princeton University Press.

Frey, Bruno S. and Alois Stutzer (2002b). What Can Economists Learn from Happiness Research? Journal of Economic Literature 40(2): 402-435.

Frey, Bruno S. and Alois Stutzer (2005). Beyond Outcomes: Measuring Procedural Utility. Oxford Economic Papers, forthcoming. 
Greenberg, Jerald (1990a). Employee Theft as a Reaction to Underpayment Inequity: The Hidden Cost of Pay Cuts. Journal of Applied Psychology 75(5): 561-570.

Greenberg, Jerald (1990b). Organizational Justice: Yesterday, Today, and Tomorrow. Journal of Management 16(2): 399-432.

Güth, Werner und Hannelore Weck-Hanneman (1997). Do People Care About Democracy? An Experiment Exploring the Value of Voting Rights. Public Choice 91(1): 27-47.

Hamilton, Barton H. (2000). Does Entrepreneurship Pay? An Empirical Analysis of Returns to Self-Employment. Journal of Political Economy 108(3), 604-632.

Harsanyi, John C. (1993). Normative Validity and Meaning of von Neumann-Morgenstern Utilities. In: Ken Binmore, Alan Kirman and Piero Tani (eds.). Frontiers of Game Theory. Cambridge, MA und London: MIT Press: 307-320.

Heider, Fritz (1958). The Psychology of Interpersonal Relations. New York: Wiley.

Hirschman, Albert O. (1973). The Changing Tolerance for Income Inequality in the Course of Economic Development. Quarterly Journal of Economics 87(4): 544-566.

Hundley, Greg (2001). Why and When Are the Self-Employed More Satisfied With Their Work? Industrial Relations 40(2), 293-317.

Idson, Todd L. (1990). Establishment Size, Job Satisfaction and the Structure of Work. Applied Economics 22, 1007-1018.

Iyengar, Sheena S. und Mark R. Lepper (2000). When Choice is Demotivating: Can One Desire Too Much of a Good Thing? Journal of Personality and Social Psychology 79(6): 995-1006.

Kahneman, Daniel, Ed Diener and Norbert Schwarz (eds) (1999). Well-Being: The Foundation of Hedonic Psychology. New York: Russell Sage Foundation.

Kahneman, Daniel, Jack L. Knetsch and Richard H. Thaler (1986). Fairness as a Constraint on Profit Seeking: Entitlements in the Market. American Economic Review 76(4): 728-741.

Kahneman, Daniel, Peter P. Wakker and Rakesh Sarin (1997). Back to Bentham? Explorations of Experienced Utility. Quarterly Journal of Economics 112(2): 375-405.

Kawaguchi, Daiji (2002). Compensating wage differentials among self-employed workers: evidence from job satisfaction scores. Institute of Social and Economic Research, Osaka University, Discussion Paper No. 568.

Khalil, Elias L. (1996). Respect, Admiration, Aggrandizement: Adam Smith as Economic Psychologist. Journal of Economic Psychology 17(5): 555-577.

Konovsky, Mary A. (2000). Understanding Procedural Justice and its Impact on Business Organizations. Journal of Management 26(3): 489-511.

Konow, James (2003). Which Is the Fairest One of All?: A Positive Analysis of Justice Theories. Journal of Economic Literature 41(4): 1188-1239.

Köszegi, Botond (2002a). Ego Utility and Information Acquisition. Mimeo. University of California at Berkeley.

Köszegi, Botond (2002b). Ego Utility, Overconfidence, and Task Choice. Mimeo. University of California at Berkeley.

Kunreuther, Howard and Paul R. Kleindorfer (1986). A Sealed-Bid Auction Mechanism for Siting Noxious Facilities. American Economic Review 76(2): 295-299. 
Kysar, Douglas A. (2004). Preferences for Processes: The Process/Product Distinction and the Regulation of Consumer Choice. Harvard Law Review 118(525): 526-624.

Lane, Robert E. (2000). The Loss of Happiness in Market Economies. New Haven and London: Yale University Press.

Langer, Ellen und Judith Rodin (1976). The Effects of Choice and Enhanced Personal Responsibility for the Aged: A Field Experiment in an Institutional Setting. Journal of Personality and Social Psychology 34(2): 191-198.

Le Menestrel, Marc (2001). A Process Approach to the Utility for Gambling. Theory and Decision 50(3): 249-262.

Lind, E. Allan and Tom R. Tyler (1988). The Social Psychology of Procedural Justice. New York: Plenum Press.

Lind, E. Allen, Carol T. Kulik, Maureen Ambrose and Maria V. de Vera Park (1993). Individual and Corporate Dispute Resolution: Using Procedural Fairness as a Decision Heuristic. Administrative Science Quarterly 38(2): 224-251.

Lind, E. Allen, Jerald Greenberg, Kimberley S. Scott and Thomas D. Welchans (2000). The Winding Road from Employee to Complainant. Administrative Science Quarterly 45(3): 557590.

Loewenstein, George (2000). Is More Choice Always Better? Working Paper, Carnegie Mellon University.

Marmot, Michael (2004). The Status Syndrome. How Social Standing Affects Our Health and Longevity. New York: Times Books.

Marmot, Michael, Hans Bosma, Harry Hemingway, Eric Brunner and Stephen Stansfeld (1997). Contribution of Job Control and Other Risk Factors to Social Variations in Coronary Heart Disease Incidence. Lancet 350(9073): 235-239.

Marschak, Jacob (1950). Uncertain Prospects, and Measurable Utility. Econometrica 18: 111141.

Moskovitz, Tobias J. and Annette Vissing-Jorgensen (2002). The Returns to Entrepreneurial Investment: A Private Equity Premium Puzzle? American Economic Review 92(4): 745-778.

Mueller, Dennis C. (2003). Public Choice III. Cambridge: Cambridge University Press.

O'Sullivan, Arthur (1993). Voluntary Auctions for Noxious Facilities: Incentives to Participate and the Efficiency of Siting Decisions. Journal of Environmental Economics and Management 25(1): 12-26.

Oswald, Andrew J. (1997). Happiness and Economic Performance. Economic Journal 107(445): 1815-1831.

Pascal, Blaise (1670). Pensées. Paris: Port-Royal.

Peterson, Christopher (1999). Personal Control and Well-Being. In: Daniel Kahneman, Ed Diener and Norbert Schwarz (eds). Well-Being: The Foundation of Hedonic Psychology. New York: Russell Sage Foundation: 288-301.

Pommerehne, Werner W. and Hannelore Weck-Hannemann (1996). Tax Rates, Tax Administration and Income Tax Evasion in Switzerland. Public Choice 88(1-2): 161-170. 
Rabin, Matthew (1993). Incorporating Fairness into Game Theory and Economics. American Economic Review 83(5): 1281-1302.

Rotemberg, Julio (2005). Customer Anger at Price Increases, Changes in the Frequency of Price Adjustment and Monetary Policy. Journal of Monetary Economics 52(4): 829-852.

Ryff, Carol D. and Corey Lee M. Keyes (1995). The Structure of Psychological Well-Being Revisited. Journal of Personality and Social Psychology 69(4): 719-727.

Sandbu, Martin (2004). Fairness and the Road Not Taken: An Experimental Test of NonReciprocal Set-Dependence in Distributive Preferences. Working Paper, Columbia University.

Schulz, Richard und Barbara H. Hanusa (1978). Long-term Effects of Control and PredictabilityEnhancing Interventions: Findings and Ethical Issues. Journal of Personality and Social Psychology 36(11): 1194-1201.

Schwartz, Barry (2000). Self-Determination: The Tyranny of Freedom. American Psychologist 55(1): 79-88.

Seligman, Martin E. P. (1992). Helplessness: On Depression, Development, and Death. New York: Freeman.

Sen, Amartya K. (1995). Rationality and Social Choice. American Economic Review 85(1): 1-24.

Sen, Amartya K. (1997). Maximization and the Act of Choice. Econometrica 65(4): 745-779.

Slemrod, Joel and Shlomo Yitzhaki (2002). Tax Avoidance, Evasion, and Administration. In: Alan J. Auerbach and Martin Feldstein (eds). Handbook of Public Economics, vol. 3. Amsterdam, London and New York: Elsevier.

Torgler, Benno (2005). Tax Morale and Direct Democracy. European Journal of Political Economy 21: 525-531.

Torgler, Benno, Christoph A. Schaltegger und Markus Schaffner (2003). Is Forgiveness Divine? A Cross-Culture Analysis of Tax Amnesties. Swiss Journal of Economics and Statistics 139: 375-396.

Tsuchiya, Aki, Luis S. Miguel, Richard Edlin, Allan Wailoo and Paul Dolan (2005). Procedural Justice in Public Healthcare Resource Allocation. Applied Health Economics and Health Policy 4(2): 119-128.

Tyler, Tom R. (1997). Procedural Fairness and Compliance with the Law. Swiss Journal of Economics and Statistics 133(2): 219-240.

Tyler, Tom R. (2003). Procedural Justice, Legitimacy, and the Effective Rule of Law. In: Tonry, M. (ed.). Crime and Justice - A Review of Research. Vol. 30. Chicago: University of Chicago Press: 431-505.

Tyler, Tom R., Robert J. Boeckmann, Heather J. Smith and Yuen J. Huo (1997). Social Justice in a Diverse Society. Boulder, CO: Westview Press.

Tyler, Tom R. and Steven L. Blader (2000). Cooperation in Groups: Procedural Justice, Social Identity, and Behavioral Engagement. Philadelphia, PA: Psychology Press.

Tyler, Tom R. and Steven L. Blader (2003). The Group Engagement Model: Procedural Justice, Social Identity, and Cooperative Behavior. Personality and Social Psychology Review 7(4): 349-361. 
Tyran, Jean-Robert and Dirk Engelmann (2005). To Buy or Not to Buy? An Experimental Study of Consumer Boycotts in Retail Markets. Economica 72(285): 1-16.

von Neumann, John and Oskar Morgenstern (1944). Theory of Games and Economic Behavior. Princeton: Princeton University Press.

Wailoo, Allan and Paul Anand (2005). The Nature of Procedural Preferences for Health-Care Rationing Decisions. Social Science and Medicine 60(2): 223-236.

White, R. Winthrop (1959). Motivation Reconsidered: The Concept of Competence. Psychological Review 66(5): 297-333.

Williamson, Oliver E. (1975). Markets and Hierarchies: Analysis and Antitrust Implications. New York: Free Press.

Zuckerman, Miron, Joseph Porac, Drew Latin, Raymond Smith und Edward L. Deci (1978). On the Importance of Self-Determination for Intrinsically Motivated Behavior. Personality and Social Psychology Bulletin 4(3): 443-446. 